\title{
SOCIOLOGIA ECONÔMICA E ESTUDOS ORGANIZACIONAIS
}

\author{
Por Maurício C. Serafim \\ Doutorando em Administração de Empresas na FGV-EAESP \\ E-mail: serafim.gv@gmail.com
}

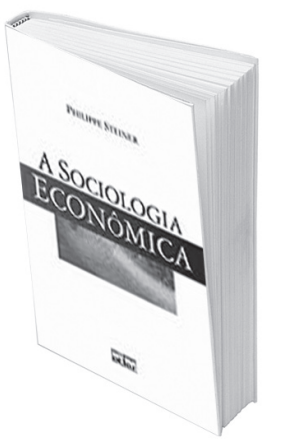

\section{A SOCIOLOGIA ECONÔMICA}

De Philippe Steiner. São Paulo: Atlas, 2006. 134 p.

Desde a década de 1980 a Sociologia Econômica (SE) está se tornando um dos campos do conhecimento mais promissores e dinâmicos das ciências sociais. Suas origens remontam ao século XIX e abrange os anos 18901920, período caracterizado por crise da economia política e da crescente institucionalização da teoria econômica marginalista. Provavelmente, o primeiro autor a empregar o termo foi William Jevons (1835-1882), no seu trabalho Teoria da economia política, de 1879; entre os autores dessa fase, também se destacam Max Weber (1864-1920), Émile Durkheim (18581917), Georg Simmel (1858-1918) e Vilfredo Pareto (1848-1923). O principal veio dessa tradição é a combinação da análise dos interesses econômicos com a análise das relações sociais.
A segunda fase da SE abrange os anos $1930-70$ e se caracteriza pelo arrefecimento dos temas propostos e investigados pelos pioneiros. Não obstante o declínio do campo, alguns autores proporcionaram avanços teóricos nesse período. Entre eles se destacam Joseph Schumpeter (18831950), Karl Polanyi (1886-1964), Talcot Parsons (1902-79) e Neil J. Smelser (1930-). Esses autores contribuíram com o desenvolvimento de conceitos como destruição criativa, empreendedorismo, imersão social (embeddedness) e teses como a de que a sociologia e a economia podem ser entendidas como partes (subsistemas) de uma teoria geral dos sistemas sociais.

A terceira fase se inicia a partir dos anos 1980 e se caracteriza pelo revigo- ramento do campo. Alguns trabalhos pioneiros desse período - como os de Harrison White e Arthur Stinchcombe - foram importantes para o setor, mas a publicação, em 1985, do ensaio teórico de Mark Granovetter "Economic action and social structure: the problem of embeddedness", é considerada o principal marco dessa retomada. Ainda em 1985, Granovetter cunhou o termo "nova sociologia econômica", para diferenciar a então vigente agenda de pesquisa daquela realizada pela "velha sociologia econômica", representada principalmente por Parsons, Smelser, e pelos pesquisadores de sociologia industrial e do trabalho.

No Brasil, um trabalho digno de nota foi realizado por Alberto Guerreiro Ramos, principalmente em sua obra A nova ciência das organizações, 
escrita durante os anos 1970 e publicada em 1981. Dentre suas principais referências, estão Weber e Polanyi, dos quais utiliza conceitos como ação e relação social, e racionalidade substantiva. Também aplica as idéias de imersão social do sistema econômico e construção social do mercado para formular sua teoria da delimitação dos sistemas sociais e o paradigma que denomina paraeconômico, uma abordagem de análise e planejamento de sistemas sociais que considera o mercado apenas uma das partes do conjunto do tecido social. Nessa obra, apesar de seu caráter analítico-normativo, Guerreiro Ramos se aproxima da velha SE, ao analisar os fenômenos econômicos sob o ponto de vista da racionalidade, e, de certa forma, também da nova SE, ao criticar os pressupostos metodológicos da economia convencional que Granovetter critica; em oposição ao conceito de que o homem é associal, onisciente e maximizador de utilidade, propõe uma categoria de análise denominada homem parentético, cujas motivações vão além do interesse econômico.

Apesar de contar com uma obra importante como a de Ramos, a SE no Brasil não seguiu o desenvolvimento do campo após os anos 1980 em países como Estados Unidos, França e Itália. Pode-se especular que uma das razões foi a falta de traduções de obras recentes, principalmente aquelas direcionadas ao ensino. E por isso a edição brasileira da obra de Philippe Steiner, A sociologia econômica, publicada originalmente em francês em 1999, é uma iniciativa bem-vinda.

O autor - sociólogo e economista francês, professor da Universidade de Lille-III - cumpre com êxito o objetivo de apresentar o campo da SE em uma perspectiva histórica e os recentes avanços científicos proporcionados por essa abordagem. Inicia afirmando que a SE "estuda os fatos econômicos como fatos sociais" (p. 1), numa clara influência de Durkheim, para quem "fato social" deve ser entendido como "coisa", isto é, possuir existência objetiva externa ao agente e capaz de influenciá-lo. Ao considerar que o primeiro é parte do segundo - fatos econômicos como fatos sociais -, a SE pressupõe que há outros aspectos que precisam ser analisados para a compreensão dos fenômenos econômicos da maneira mais completa possível. Tais aspectos compreendem a construção social das instituições e o pressuposto de que a ação econômica é sempre socialmente localizada e, por isso, influenciada pela estrutura social e pela cultura. Em seguida, o autor esclarece o procedimento da SE, que a distingue da economia: para a explicação dos comportamentos, devem-se identificar as mediações sociais e as formas de coordenação entre os dados e os fenômenos estudados.

A partir daí, Steiner identifica com didatismo os limites da economia convencional acerca da análise de fenômenos econômicos. Com o intuito de deixar mais evidente a crítica e a contribuição da SE, o autor adota o mercado como objeto de análise central do livro, e discorre sobre alguns dos trabalhos teóricos e empíricos mais relevantes e inovadores da área. Dentre esses trabalhos, escolhe os que abordam a construção social das relações mercantis (como mercado, moeda, finanças, mercado de trabalho, concorrência,), as redes sociais (com ênfase em imersão estrutural, capital social, emprego e carreira, papel da confiança, força dos vínculos fracos e buraco estrutural) e a imersão cognitiva (com ênfase em representações sociais, crenças coletivas e no exemplo do mercado financeiro). Uma ressalva importante feita por Steiner é que a SE não pretende ser antagônica à economia, pretendendo antes retomar o diálogo interrompido por 60 anos, oferecendo-lhe alternativas analíticas de modo que, juntas, possam produzir uma melhor compreensão de seus fenômenos de interesse.

Para o campo dos Estudos Organizacionais, a SE pode contribuir com o seu instrumental crítico, analítico e teórico para o desenvolvimento dos temas de teoria institucional, empreendedorismo, carreira, comportamento e cultura organizacional, estratégia como construção social, mudança organizacional, relação empresa-sociedade, arranjos produtivos e grupos de negócios. No Brasil, uma das teorias mais promissoras da SE é a das redes sociais, que é utilizada, por exemplo, na compreensão da formação de redes entre empresas, sua influência nas mudanças organizacionais e na inovação, e a influência das relações de confiança entre empresas na definição de estratégias empresariais.

Três observações podem ser feitas à edição brasileira, tendo em vista o público de interesse. A primeira é com respeito ao conceito de embeddedness, que na obra foi traduzido por "inserção". Talvez tivesse merecido uma nota explicativa para orientar o leitor sobre as diversas traduções que vem recebendo, tais como "imersão" (utilizado na apresentação do livro), "enraizamento", "incrustação" e "imbricação". A segunda observação refere-se aos títulos das obras mencionadas, que ao longo do texto permaneceram em francês, inclusive os que já foram publicados no Brasil, o que pode limitar seu caráter didático. E a terceira é que alguns autores citados não estão nas referências ao final do livro, enquanto outros possuem informações incompletas de suas obras. No entanto, esses pontos de atenção não desmerecem o livro, que certamente deverá ser indicado como uma sofisticada introdução à SE. 